\title{
Crude glycerin combined with sugar cane silage in lamb diets
}

\author{
Carlos Alberto Alves de Oliveira Filho ${ }^{1}$. José Augusto Gomes Azevêdo ${ }^{1,8}$. \\ Gleidson Giordano Pinto de Carvalho ${ }^{2}$. Camilla Flávia Portela Gomes da Silva ${ }^{3}$. \\ Ícaro dos Santos Cabral ${ }^{4}$. Luiz Gustavo Ribeiro Pereira ${ }^{5} \cdot$ Larissa Gomes dos Reis $^{6}$. \\ Flávio Moreira de Almeida ${ }^{7}$. Lígia Lins Souza ${ }^{7}$
}

Received: 9 April 2015 / Accepted: 26 October 2015

(C) Springer Science+Business Media Dordrecht 2015

\begin{abstract}
This study aimed to evaluate the effect of the level of crude glycerin $(\mathrm{CG})$ on in vitro fermentation kinetics $(0,20$, 40,60 , and $80 \mathrm{~g} / \mathrm{kg} \mathrm{DM}$ of sugar cane silage), on in vitro neutral detergent fiber (NDF) degradation $(0,30,60$, and $90 \mathrm{~g} / \mathrm{kg}$ DM of sugar cane silage), and intake and digestibility of nutrients and nitrogen balance $(0,20,55,82$, and $108 \mathrm{~g} / \mathrm{kg}$ $\mathrm{DM}$ of sugar cane silage) in lambs. The in vitro trials were conducted in a completely randomized design with three repetitions. The in vivo trial was conducted in a Latin square design with five repetitions $(5 \times 5)$. For variables in which the $F$ test was considered significant, the statistical interpretation of the effect of CG substitution levels was carried out through regression analyses. Kinetic parameters were not affected by CG inclusion. On in vitro NDF degradation, a significant effect of CG levels was observed on the potentially degradable fraction of NDF, the insoluble potentially degradable fraction of NDF, and the undegradable NDF fraction. The intake and
\end{abstract}

José Augusto Gomes Azevêdo augustog@uesc.br

1 Universidade Estadual de Santa Cruz, Ilhéus, Bahia, Brazil

2 Universidade Federal da Bahia, Salvador, Bahia, Brazil

3 Instituto Federal Baiano, Santa Inês, Bahia, Brazil

4 Universidade Federal do Amazonas, Parintins, Amazonas, Brazil

5 EMBRAPA Gado de Leite, Juiz de Fora, Minas Gerais, Brazil

6 Universidade Federal de Juiz de Fora, Juiz de Fora, Minas Gerais, Brazil

7 Universidade Estadual do Sudoeste da Bahia, Itapetinga, Bahia, Brazil

8 Departamento de Ciências Agrárias e Ambientais, Universidade Estadual de Santa Cruz, Km 16 - Rodovia Jorge Amado, CEP: 45.662-900 Ilhéus, Bahia, Brazil digestibility of nutrients and nitrogen balance were not affected by $C G$ inclusion. The CG levels change in vitro NDF degradability parameters; however, there were no changes in animal intake, digestibility, and nitrogen balance with the inclusion levels used.

Keywords Alternative food · By-product · Glycerol · Nutritional value $\cdot$ Roughage

\section{Introduction}

Crude glycerin (CG), a byproduct chemically based on glycerol, has aroused interest from the scientific community for its use as an alternative energy source in ruminant diets. The effects of using it as a substitute for corn on performance, dry matter intake, and nutritional factors have been reported in literature (Donkin et al. 2007; Parsons et al. 2009). The effects of glycerol on food fermentation patterns, rumenmicroflora, in vivo digestibility, and nitrogen compound balance are however scarce for small ruminants, especially when tropical roughage is used.

Changes in ruminal fermentation caused by the inclusion of alternative foods may alter the amount of nutrients ingested that are capable to be absorbed, which depends on ruminal fermentation rate and residence time for microbial attack, and because the effective degraded fraction is a function of degradation and passage rates. The rate and extent of ruminal degradation also depend on the nature and content of cell wall components and on the availability of ruminal nitrogen. In this way, systems of chemical analysis with ruminal degradation kinetics enable a more accurate estimation of forage nutritive values (Mello et al. 2006).

This study aimed to evaluate the effect of different levels of $\mathrm{CG}$ on in vitro ruminal fermentation kinetics, in vitro neutral 
detergent fiber (NDF) degradation kinetics, dry matter consumption and digestibility, and nitrogen balance in lambs fed on sugar cane silage.

\section{Materials and methods}

The experiment was conducted in the Research Laboratory in Ruminant Nutrition and Feeding (Laboratório de Pesquisaem Nutrição e Alimentação de Ruminantes-LaPNAR) of the Department of Agricultural and Environmental Sciences at the State University of Santa Cruz (Universidade Estadual de Santa Cruz-UESC), Ilhéus, Bahia, Brazil.

For sugar cane silage production, the sugar cane cultivar RB-72454 was used 18 months post-regrowth. To evaluate fermentation kinetics, in vitro gas production technique was used as described by Mauricio et al. (1999). In vials of $50 \mathrm{~mL}$, $0.3 \mathrm{~g}$ of the sugar cane silage and $28.125 \mathrm{~mL}$ of a culture medium were added (Theodorou et al. 1994), along with levels of CG $(0,20,40,60$, and $80 \mathrm{~g} / \mathrm{kg}$ DM sugar cane silage) in triplicate for each treatment. The chemical compositions of sugar cane silage and crude glycerin used in the incubation can be observed in Table 1 .

Gas pressure was measured at $0,1,2,3,4,6,8,10$, $12,14,16,18,20,24,28,36,48,60,72,84,96,108$, 120 , and $144 \mathrm{~h}$ after fermentation was commenced $(0 \mathrm{~h})$. Pressure measurements were converted to volume according to the equation estimated by Santos et al. (2010):
$V=0.04755+1.9754 * p+0.01407 * p^{2}$, where $V$ is gas volume $(\mathrm{mL})$ and $p$ is the gas pressure in the fermentation bottles (psi).

The kinetic parameters of cumulative gas production were evaluated according to the bi-compartmental model of Schofield et al. (1994): $V=V f 1 / 1+\exp (2-4 \times \mathrm{C} 1 \times(\mathrm{T}-\mathrm{L}))+$ $V f 2 / 1+\exp (2-4 \times \mathrm{C} 2 \times(\mathrm{T}-\mathrm{L}))$, where $V$ is the volume of gas accumulated at time $t ; V f 1$ is the maximum gas volume of the rapidly digested NFC (non-fibrous carbohydrates) fraction; $\mathrm{C} 1$ corresponds to the degradation rate $(\mathrm{mL} / \mathrm{h})$ of this same fraction (NFC); $V f 2$ corresponds to the maximum gas volume of the slowly degraded CF (fibrous carbohydrate) fraction; $\mathrm{C} 2$ represents the $\mathrm{CF}$ degradation rate $(\mathrm{mL} / \mathrm{h})$ and $\mathrm{T}$ and $\mathrm{L}$ refer to incubation time (hours) and latency (hours), respectively. The maximum gas volume (TV) produced was obtained by the sum of $V f 1$ and $V f 2$.

To evaluate neutral detergent fiber (NDF) degradation kinetics by gravimetric technique, the same model of incubation described for in vitro gas production was used, adopting 0,2 , $4,8,12,24,48,60,72,96,120,144$, and 264 h postincubation as measuring times.

The treatments contained $0,30,60$, and $90 \mathrm{~g} \mathrm{CG}$ per $\mathrm{kg}$ DM of sugar cane silage. An exponentially decreasing function model corrected for latency time as described by Sampaio et al. (1995) was used to estimate the parameters: $Y=\mathrm{A}-\mathrm{B} * \exp \left(-c^{*} t\right)$, where $Y$ is the residue of NDF at time $t$; $\mathrm{A}$ is the potentially degradable fraction of NDF; $\mathrm{B}$ is the insoluble potentially degradable fraction of NDF; exp is the base of the Neperian logarithm; $c$ is the degradation rate of

Table 1 Chemical composition of ingredients and diets and ingredient proportion according to the levels of crude glycerin included

\begin{tabular}{|c|c|c|c|c|c|c|c|}
\hline \multirow[t]{2}{*}{ Composition } & & & \multicolumn{5}{|c|}{ Level of crude glycerin (g/kg DM) } \\
\hline & & & 0 & 28 & 55 & 82 & 108 \\
\hline \multicolumn{8}{|l|}{ Ingredient (g/kg DM) } \\
\hline Sugar cane silage & & & 945.2 & 918.5 & 892.5 & 866.9 & 841.6 \\
\hline Crude glycerin & & & 0.0 & 27.8 & 55.0 & 81.9 & 108.4 \\
\hline Urea & & & 40.9 & 39.9 & 38.7 & 37.6 & 36.5 \\
\hline Mineral suplementation ${ }^{(a)}$ & & & 14.0 & 14.0 & 13.9 & 13.8 & 13.7 \\
\hline Chemical composition & Sugar cane silage & Crude glycerin & & & & & \\
\hline Dry matter (g/kg) & 166.0 & 800.0 & 211.3 & 228.1 & 244.3 & 260.4 & 276.2 \\
\hline Organic matter (g/kg DM) & 955.3 & 965.0 & 903.0 & 877.4 & 852.7 & 828.1 & 804.1 \\
\hline Crude protein (g/kg DM) & 28.3 & - & 141.5 & 137.6 & 133.6 & 129.7 & 125.9 \\
\hline $\mathrm{NDFap}^{(\mathrm{b})}$ (g/kg DM) & 676.6 & - & 639.5 & 621.4 & 603.8 & 586.4 & 569.3 \\
\hline Non-fibrous carbohydrate (g/kg DM) & 234.7 & - & 107.3 & 100.6 & 94.5 & 88.3 & 82.3 \\
\hline Ether extract (g/kg DM) & 15.6 & 125.0 & 14.7 & 17.8 & 20.8 & 23.7 & 26.6 \\
\hline Acid detergent fiber (g/kg DM) & 505.6 & - & 468.5 & 455.3 & 442.5 & 429.8 & 417.3 \\
\hline Lignin (g/kg DM) & 77.1 & - & 72.8 & 70.8 & 68.8 & 66.8 & 64.9 \\
\hline Total digestible nutrients (g/kg DM) & - & - & 540.3 & 560.1 & 610.3 & 500.4 & 500.2 \\
\hline
\end{tabular}

${ }^{\mathrm{a}}$ Composition (per 1 kg product): Ca, 130-150 g; P, 65 g; Na, 130 g; Mg, 10 g; S, 12 g; F, 650 mg; Mn, 3000 mg; Zn, 5000 mg; Co, 80 mg; Fe, 1000 mg; Se, $10 \mathrm{mg} ; \mathrm{I}, 60 \mathrm{mg}$

${ }^{\mathrm{b}} \mathrm{NDFap}=$ neutral detergent fiber corrected for ash and protein 
fraction B per unit of time $\left(/ \mathrm{h}^{-1}\right)$; and $t$ is the incubation time (h). The undegradable fraction (I) was considered as 100-A.

For the in vivo experiment, five male lambs of undefined breed were used, with a mean starting weight of $22.83 \pm$ $5.49 \mathrm{~kg}$, randomly distributed in a $5 \times 5$ Latin square design with five $C G$ inclusion levels and five collection periods, according to the mathematical model: $Y_{i j(k)}=m+P_{i}+A_{j}+t_{k}+\varepsilon_{i j(k)}$, in which, $Y_{i j}=$ variable response, $m=$ general mean, $P_{i}=$ effect of period $i, A_{j}=$ effect of animal $j, t_{k}=$ effect of treatment $k$, and $\varepsilon_{i j(k)}=$ experimental error.

To each animal or experimental unit, one of five treatments was randomly assigned, constituted of $0,20,40,60$, and $80 \mathrm{~g} / \mathrm{kg}$ natural matter (NM) of sugar cane silage, representing $0,28,55,82$, and $108 \mathrm{~g} \mathrm{CG} / \mathrm{kg} \mathrm{DM}$ sugar cane silage, respectively (Table 1).

The experiment was carried out over 105 days. Each experimental period consisted of 21 days, with 16 days of adaptation and 5 days of collection. Total fecal collection was carried out from the 17 th to 21 st day using synthetic leather collection bags. Urine samples were obtained from all lambs for total urine collection in recipient buckets placed on the floor, containing $100 \mathrm{~mL}$ sulfuric acid $(20 \% v / v)$ during the five experimental days.

Samples of the silage provided, feces, and leftovers were subjected to analyses of dry matter (DM), crude protein (CP), ether extract (EE), and mineral matter (MM) according to Association of Official Analytical Chemistry-AOAC (1990). For neutral detergent fiber (NDF) analysis, the analytical procedure proposed by Nocek (1988), Mertens (1992), and Licitra et al.(1996) was used. Lignin content was obtained according to Van Soest and Robertson (1985). Non-fibrous carbohydrate (NFC), expressed in \% DM, was calculated according to Hall (2000) as follows: $100-(\% \mathrm{NDF}+\% \mathrm{CP}+\% \mathrm{EE}+\% \mathrm{MM})$.

Digestibility was calculated using the formula: ADC $\mathrm{g} / \mathrm{g}=[\mathrm{NCON}-\mathrm{NEXC} / \mathrm{NCON}] \times 100$, in which, $\mathrm{ADC}=$ coefficient of apparent nutrient digestibility, $\mathrm{NCON}=$ amount of nutrient consumed $(\mathrm{g})$, and $\mathrm{NEXC}=$ amount of nutrients excreted (g). DM intake and nutritional compounds were obtained by the difference between feed offered and leftovers after $24 \mathrm{~h}$. Nitrogen compounds were calculated by the difference between nitrogen ingested (NI) and nitrogen excreted (urine and feces).

Statistical analyses for the evaluation of fermentation and degradation kinetics in vitro were conducted in a completely randomized design with three repetitions. For the in vivo trial, statistical analyses were conducted in a Latin square design with five repetitions. For variables in which the $F$ test was considered significant, the statistical interpretation of the effect of CG substitution levels was carried out through regression analyses. All statistical procedures were carried out in the statistical program SAS, meeting all presuppositions for the errors.

\section{Results}

There was no significant effect $(P>0.05)$ for any kinetic parameters of in vitro ruminal fermentation evaluated according to different CG levels (Table 2).

Regarding the parameters adjusted from in vitro NDF degradation kinetics of sugar cane silage, a significant effect of CG levels $(P<0.05)$ was observed on the potentially degradable fraction of NDF (A), the insoluble potentially degradable fraction of NDF (B), and the undegradable NDF fraction (I) (Table 3).

The fraction A (\%) was $8.49 \%$ higher for the substrate with $90 \mathrm{~g} / \mathrm{kg}$ DM of CG as compared to the control substrate. On the other hand, fractions B (\%) and I (\%) were respectively 49.90 and $10.86 \%$ lower for the substrate containing $90 \mathrm{~g} / \mathrm{kg}$ MS of CG as compared to the control substrate.

Table 2 Estimation of kinetic parameters of in vitro gas production of sugar cane silage according to levels to crude glycerin and adjusted by regression equations

\begin{tabular}{|c|c|c|c|c|c|c|c|}
\hline \multirow[t]{2}{*}{ Parameters } & \multicolumn{5}{|c|}{ Level of crude glycerin (g/kg DM) } & \multirow[t]{2}{*}{ SEM } & \multirow{2}{*}{$\begin{array}{l}\text { Regression } \\
\text { equations* }\end{array}$} \\
\hline & 0 & 20 & 40 & 60 & 80 & & \\
\hline$V f 1\left(\mathrm{~mL} \mathrm{~g}^{-1}\right)$ & 36.85 & 39.42 & 44.75 & 43.24 & 47.17 & 1.3938 & $\hat{\mathrm{Y}}=42.28$ \\
\hline $\mathrm{C} 1\left(\mathrm{~mL} \mathrm{~h}^{-1}\right)$ & 0.107 & 0.109 & 0.110 & 0.096 & 0.099 & 0.0028 & $\hat{\mathrm{Y}}=0.104$ \\
\hline $\mathrm{L}(\mathrm{h})$ & 8.06 & 7.74 & 8.27 & 7.89 & 7.62 & 0.0943 & $\hat{\mathrm{Y}}=7.91$ \\
\hline$V f 2\left(\mathrm{~mL} \mathrm{~g}^{-1}\right)$ & 156.29 & 158.33 & 153.59 & 151.10 & 145.75 & 1.8192 & $\hat{\mathrm{Y}}=153.01$ \\
\hline $\mathrm{C} 2\left(\mathrm{~mL} \mathrm{~h}^{-1}\right)$ & 0.017 & 0.0154 & 0.017 & 0.017 & 0.017 & 0.0072 & $\hat{\mathrm{Y}}=0.017$ \\
\hline $\mathrm{TV}\left(\mathrm{mL} \mathrm{g}{ }^{-1} \mathrm{DM}\right)$ & 193.14 & 197.75 & 198.34 & 194.33 & 192.92 & 1.2096 & $\hat{Y}=195.29$ \\
\hline
\end{tabular}

$V f 1$ maximum gas volume of the NFC (non-fibrous carbohydrate) fraction, $C 1$ degradation rate of NFC fraction, $L$ latency time, $V f 2$ maximum gas volume of the FC (fibrous carbohydrate) fraction, $C 2$ degradation rate of FC, TV maximum gas production volume from total carbohydrates, SEM standard error of the mean

$* \alpha=0.05$ probability for Type I error 
Table 3 Adjusted kinetics parameters of in vitro NDF degradation of sugar cane silage with different levels of crude glycerin, adjusted by regression equations and the correlation coefficient $\left(R^{2}\right)$

\begin{tabular}{llllllll}
\hline Parameters & \multicolumn{3}{l}{ Level of crude glycerin (g/kg DM) } & SEM & Regression equations* & $R^{2}$ \\
\cline { 2 - 5 } & 0 & 30 & 60 & 90 & & & \\
\hline A (\%) & 53.59 & 54.47 & 56.60 & 58.14 & 0.690 & $\hat{\mathrm{Y}}=53.3328+0.526 \mathrm{x}$ & 0.91 \\
B $(\%)$ & 32.50 & 27.18 & 24.50 & 21.68 & 1.520 & $\hat{\mathrm{Y}}=31.7361-1.171 \mathrm{x}$ & 0.95 \\
$\mathrm{C}\left(\mathrm{h}^{-1}\right)$ & 0.03 & 0.04 & 0.03 & 0.03 & 0.001 & $\hat{\mathrm{Y}}=0.034$ & - \\
I $(\%)$ & 46.41 & 45.53 & 43.40 & 41.86 & 0.690 & $\hat{\mathrm{Y}}=46.6671-0.526 \mathrm{x}$ & 0.91 \\
\hline
\end{tabular}

$A$ potentially degradable fraction of NDF, $B$ insoluble potentially degradable fraction, $C$ degradation rate of fraction B per unit of time, $I$ undegradable fraction of NDF, SEM standard error of the mean

$* \alpha=0.05$ probability for Type I error
Regarding the in vivo trial, CG inclusion in sugar cane silage up to $108 \mathrm{~g} / \mathrm{kg}$ DM did not affect $(P>0.05)$ the intake of DM, OM, NDFap, CP, NFC, EE, and TDN (Table 4).

The inclusion of CG up to $108 \mathrm{~g} / \mathrm{kg}$ DM in sugar cane silage did not influence $(P>0.05)$ the apparent digestibility coefficients of DM, OM, NDFap, NFC, CP, and EE (Table 5).

There was no significant effect $(P>0.05)$ observed for the levels of $\mathrm{CG}$ on consumed, fecal, urinary, or retained $\mathrm{N}$ (g/animal/day) (Table 6).

\section{Discussion}

The values observed for the kinetic parameters studied can be better associated with the chemical composition of the silage than the inclusion of CG.

The inclusion of CG at up to $80 \mathrm{~g} / \mathrm{kg}$ DM sugar cane silage did not affect the adherence of rumen microflora to the food particles (stage prior to degradation), growth, and bacteria activity during the fermentation of sugar cane silage, which can be observed by the non-significant effect $(P>0.05)$ obtained for latency time (L) $(Y=7.91 \mathrm{~h})$ (Table 2).

No significant effect $(P>0.05)$ of CG levels was observed for TV ( $\mathrm{mL} \mathrm{g}^{-1} \mathrm{MS}$ ), presenting a mean value of $195.29 \mathrm{~mL} \mathrm{~g}^{-1} \mathrm{DM}$. The value observed for total gas production is possibly related to the low NFC value of sugar cane silage, as shown by the chemical composition (Table 1).

Oliveira Filho et al. (2015) evaluated the addition of CG up to $80 \mathrm{~g} / \mathrm{kg} \mathrm{DM}$ in sorghum silage, and only observed differences in volume and rate of digestion of non-fibrous carbohydrate ( $V f 1$ and $\mathrm{C} 1)$, indicating a need for research to evaluate which kinds of rumen microorganisms, mainly bacteria, are more sensitive to high levels of CG.

The mechanism of action of CG (glycerol) on ruminal microorganisms is still unknown. It is however believed that glycerol can make the substrate less accessible to microbial cells due to an inhibitory action of glycerol through inhibiting or altering the action target of cellulases from microorganism or through modifying its affinity to the substrate and to the
Table 4 Intake of nutritional factors and total digestible nutrients (TDN) in lambs fed on sugar cane silage and crude glycerin

\begin{tabular}{|c|c|c|c|c|c|c|c|}
\hline \multirow[t]{2}{*}{ Item } & \multicolumn{5}{|c|}{ Level of crude glycerin (g/kg DM) } & \multirow[t]{2}{*}{ SEM } & \multirow{2}{*}{$\begin{array}{l}\text { Regression } \\
\text { equations* }\end{array}$} \\
\hline & 0 & 28 & 55 & 82 & 108 & & \\
\hline dry matter (g/day) & 258.62 & 278.62 & 276.96 & 269.26 & 240.18 & 20.2 & $\hat{Y}=264.7$ \\
\hline Organic matter (g/day) & 226.84 & 236.18 & 224.88 & 202.4 & 164.3 & 18.9 & $\hat{Y}=210.9$ \\
\hline Crude protein (g/day) & 40.64 & 40.92 & 40.38 & 35.86 & 30.92 & 2.6 & $\hat{Y}=37.7$ \\
\hline NDFap (g/day) & 154.92 & 164.3 & 178.2 & 149.26 & 126.98 & 12.8 & $\hat{Y}=154.7$ \\
\hline NFC (g/day) & 73.94 & 71.96 & 67.74 & 63.42 & 55.3 & 5.2 & $\hat{\mathrm{Y}}=66.4$ \\
\hline Ether extract (g/day) & 3.33 & 4.56 & 5.36 & 4.94 & 4.21 & 0.4 & $\hat{Y}=4.6$ \\
\hline TDN (g/day) & 129.95 & 178.46 & 170.46 & 153.07 & 139.50 & 20.4 & $\hat{Y}=154.3$ \\
\hline Dry matter (g/kg LW) & 11.66 & 13.15 & 13.72 & 11.82 & 10.59 & 1.0 & $\hat{\mathrm{Y}}=12.19$ \\
\hline Dry matter $\left(\mathrm{g} / \mathrm{kg}^{0.75}\right)$ & 25.15 & 28.07 & 28.89 & 25.69 & 23.10 & 2.0 & $\hat{Y}=26.18$ \\
\hline NDFap (g/kg LW) & 7.00 & 7.74 & 8.59 & 6.55 & 5.57 & 0.6 & $\hat{Y}=7.09$ \\
\hline NDFap $\left(\mathrm{g} / \mathrm{kg}^{0.75}\right) \mathrm{g}$ & 15.08 & 16.53 & 18.21 & 14.23 & 12.17 & 1.2 & $\hat{\mathrm{Y}}=15.24$ \\
\hline
\end{tabular}

NDFap neutral detergent fiber corrected for ash and crude protein, $N F C$ non-fibrous carbohydrates, TDN total digestible nutrients, $S E M$ standard error of the mean, $L W$ live weight

$*^{*} \alpha=0.05$ probability of Type I error 
Table 5 Apparent digestibility coefficients of nutritional factors and total digestive nutrients in lambs fed on sugar cane silage associated with levels of crude glycerin

\begin{tabular}{llllllll}
\hline Digestibility & \multicolumn{4}{l}{ Level of crude glycerin $(\mathrm{g} / \mathrm{kg} \mathrm{DM})$} & & SEM & $\begin{array}{c}\text { Regression } \\
\text { equations* }\end{array}$ \\
\cline { 2 - 6 } & 0 & 28 & 55 & 82 & 108 & & \\
\hline Dry matter $(\mathrm{g} / \mathrm{g})$ & 0.51 & 0.45 & 0.50 & 0.43 & 0.39 & 0.02 & $\hat{\mathrm{Y}}=0.45$ \\
Organic matter $(\mathrm{g} / \mathrm{g})$ & 0.48 & 0.39 & 0.47 & 0.34 & 0.60 & 0.03 & $\hat{\mathrm{Y}}=0.46$ \\
NDFap $(\mathrm{g} / \mathrm{g})$ & 0.42 & 0.32 & 0.45 & 0.33 & 0.41 & 0.03 & $\hat{\mathrm{Y}}=0.39$ \\
NFC (g/g) & 0.74 & 0.73 & 0.74 & 0.69 & 0.74 & 0.01 & $\hat{\mathrm{Y}}=0.72$ \\
Crude protein $(\mathrm{g} / \mathrm{g})$ & 0.83 & 079 & 0.82 & 0.78 & 0.77 & 0.01 & $\hat{\mathrm{Y}}=0.80$ \\
Ether extract $(\mathrm{g} / \mathrm{g})$ & 0.40 & 0.45 & 0.55 & 0.49 & 0.70 & 0.04 & $\hat{\mathrm{Y}}=0.54$ \\
\hline
\end{tabular}

NDFap neutral detergent fiber corrected for ash and protein, $N F C$ non-fibrous carbohydrates, $T D N$ total digestive nutrients, SEM standard error of the mean

$* \alpha=0.05$ probability of Type I error alteration on bacteria wall cell permeability by glycerol, which modifies cellulose excretion (Rogers et al. 1992).

In this study, no inhibitory effects from CG (glycerol) were observed on kinetic parameters evaluated, which can be verified by the non-significant effect $(P>0.05)$ of CG level on $\mathrm{L}$, $V f 1, \mathrm{C} 1, V f 2, \mathrm{C} 2$, and TV values (Table 2). Similar results for TV (mL g DM) were obtained (Meale et al. 2013 and Avila et al. 2011) using crude glycerin concentrations in diets of wheat grain (12\% DM) and barley grains (21\% DM), respectively.

The mean value of $\mathrm{C} 1\left(0.105 \mathrm{~h}^{-1}\right)$ observed for sugar cane silage was observed to be below the limits described by Lanzas et al. (2007). This finding can be related to the fact that the NFC fraction of sugar cane silage is constituted by reminiscent soluble sugars and organic acids, in which the latter presents instantaneous ruminal degradation and the soluble sugar contributes as an energetic substrate promptly available for ruminal fermentation.

Differences in fiber digestibility can also be attributed to the ability that microorganisms have to adapt to CG in the diet (Parsons and Drouillard 2010) and as the rate of glycerol disappearance can increase with time, NDF degradability can be potentially improved due to the adaptation of ruminal microorganisms (Krehbiel 2008).

The inclusion of CG favored digestibility of fraction A of sugar cane silage, with an increase of $0.526 \%$ in degradation estimated for each $10 \mathrm{~g}$ of CG per kg of DM (Table 3). This result can be related to the higher ability of microorganisms to use an energetic substrate (glycerol) in microbial activity, because sugar cane silage has a lower availability of soluble carbohydrate due to the consumption of these compounds during the fermentative process in the silo. The associative effect among energetic sources in the silage (NFC) and CG (glycerol) can favor fraction A degradation. Consequently, the inclusion of CG linearly reduced $(P<0.05)$ the insoluble potentially degradable fraction of NDF (B), with a $1.71 \%$ decrease in the degradability of this fraction for each $10 \mathrm{~g} \mathrm{CG} / \mathrm{kg}$ DM. The same behavior was observed for the undegradable fraction of NDF (I) $(P<0.05)$ with a $0.526 \%$ decrease for each $10 \mathrm{~g} \mathrm{CG} / \mathrm{kg}$ DM (Table 3).

The degradation rate $(C)$ of the insoluble potentially degradable fraction of NDF of sugar cane silage was not affected by the inclusion of different CG levels $(P>0.05)$, with a mean value of $0.0343 \mathrm{~h}^{-1}$ estimated (Table 3 ). These findings allow the inference that although the inclusion of CG interferes with fraction $\mathrm{B}$ degradation; its degradation rate remains constant.

Similar results for fractions B and C were obtained by Oliveira Filho et al. (2015) when evaluating the inclusion of CG up to $90 \mathrm{~g}$ per kg DM of sorghum silage. Peripolli et al. (2014), however, did not observe differences in ruminal degradation parameters of NDF when evaluating the substitution of corn by glycerol at levels up to $12 \%$.
Table 6 Daily mean values of nitrogen balance in lambs fed with sugar cane silage associated with levels of crude glycerin

\begin{tabular}{llllllll}
\hline Nitrogen & \multicolumn{3}{l}{ Level of crude glycerin (g/kg DM) } & & SEM & $\begin{array}{c}\text { Regression } \\
\text { equations* }\end{array}$ \\
\cline { 2 - 6 } & 0 & 28 & 55 & 82 & 108 & & \\
\hline Consumed (g/day) & 6.51 & 6.55 & 6.46 & 5.72 & 4.95 & 0.42 & $\hat{\mathrm{Y}}=6.04$ \\
Fecal (g/day) & 1.08 & 1.22 & 1.16 & 1.22 & 1.02 & 0.07 & $\hat{\mathrm{Y}}=1.14$ \\
Urinary (g/day) & 3.33 & 2.80 & 2.48 & 2.60 & 2.96 & 0.20 & $\hat{\mathrm{Y}}=2.83$ \\
Retained (g/day) & 2.09 & 2.53 & 2.83 & 1.92 & 0.96 & 0.42 & $\hat{\mathrm{Y}}=2.06$ \\
\hline
\end{tabular}

SEM standard error of the mean

${ }^{*} \alpha=0.05$ probability of Type I error 
The non-significant effect $(P>0.05)$ of CG levels on DM intake and a similar proportion of nutritional compounds in the diets can explain the non-significant $(P>0.05)$ effect of CG levels on OM, NDFap, CP, NFC, EE, and TDN intake.

These results can be associated more with the chemical composition of sugar cane silage than to CG. The low voluntary ingestion can be attributed to the NDF content of sugar cane silage showing low fiber quality, which could also be observed through the apparent digestibility coefficient of NDFap in the digestive tract totaling $0.3854 \mathrm{~g} / \mathrm{g}$ (Table 5), which probably influenced the rate of digestion passage.

In addition, the NDF level of the forage cannot be considered as the only limiting factor of forage consumption. Factors such as the chemical composition of NDF (lignin type and content and their physical-chemical interaction with the other components), dimension of potentially degradable (NDFpd) and undegradable (NDFi) fractions, initial size, density, and fragility of particles, as well as the ruminal microbial activity should be considered as directly affecting the parameters of degradation and transit dynamics through the digestive tract, which modulate the effects of NDF on the consumption and digestion of nutrients (Lund et al. 2007).

Barros et al. (2015), Lage et al. (2014), and Gunn et al. (2010) found negative linear responses over the DM intake in lambs, evaluating CG inclusions of up to $10.84,12$, and $20 \%$ of the diet, respectively. Moreover, Souza et al. (2015) reported increases in DM, EE, and NDFap intake with the inclusion of $60 \mathrm{~g} \mathrm{CG} / \mathrm{kg} \mathrm{DM}$ in the diet of lambs in confinement. The authors attributed the increased intake of NDFap, to selective intake of roughage fraction, in a possible attempt to meet the nutritional needs, since the large proportion of the diet was $300 \mathrm{~g} / \mathrm{kg}$.

In accordance with the present work, Avila-Stagno et al. (2013), Chanjula et al. (2015), and Oliveira Filho et al. (2015) found no differences in DM and nutrient intake in lambs fed diets with inclusion levels of 21, 20, and $7 \%$ CG in DM, respectively.

Although an influence has not been observed $(P>0.05)$, the inclusion of CG on DM and nutritional compounds digestibility, it has been observed in the literature that adding CG can adversely affect the cellulolytic activity in the rumen, decreasing digestion of fibers (Rogers et al. 1992;. Paggi et al. 2004). However, in this study, no differences were observed in apparent digestibility coefficients of DM, OM, NDFap, NFC, CP, and EE (Table 5).

Similar results in the present study were also obtained by Oliveira Filho et al. (2015) and Avila-Stagno et al. (2013) that did not verify differences in the apparent digestibility coefficients of DM, CP, and NDFap. In general, the absence of glycerol effects on in vivo digestibility (Krueger et al. 2010) and in vitro digestibility (Avila et al. 2011) has been reported in the literature.
No significant effects were observed for the levels of sugar cane silage $(0,28,55,82$, and $108 \mathrm{~g} / \mathrm{kg} \mathrm{DM})$ on $\mathrm{N}$ ingestion (6.04 g/day), fecal excretion ( $1.14 \mathrm{~g} /$ day $)$, and urinary excretion $(2.83 \mathrm{~g} /$ day $)$, resulting in a positive nitrogen balance of $2.06 \mathrm{~g} /$ day. This fact may have led to an inference of equilibrium and synchrony of protein and energy sources of the diets, as the protein to energy ratio did not affect nitrogen retention.

The increase of glycerol with the inclusion of CG levels probably did not affect the growth of bacteria and, consequently, $\mathrm{N}$ retention, as when the CG quantity was elevated, no differences in retained $\mathrm{N}$ quantity were observed $(P>0.05)$.

\section{Conclusion}

The CG levels analyzed altered the in vitro NDF degradability parameters; however, there were no changes found relating to parameters of in vitro fermentation kinetics and animal intake, digestibility, and nitrogen balance when the levels of CG inclusion used were altered.

Acknowledgments The authors acknowledge the financial support of CNPq (MCT/CNPq-Process Number 475129/2010-5), Universidade Estadual de Santa Cruz, Fundação de Amparo à Pesquisa do Estado da Bahia, and Banco do Nordeste do Brasil.

\section{Compliance with ethical standards}

Conflict of interest The authors declare that they have no competing interests.

Statement of animal rights The use of the lambs in the experiment was approved by the Ethics Committee on Animal Use of the State University of Santa Cruz, under the Protocol 033, 034, and 035/2010.

\section{References}

Association of Official Analytical Chemistry - AOAC., 1990, Agricultural Chemists, (Official Methods Of Analysis, Washington)

Avila, J.S., Chaves, A.V., Hernandez-Calva, M., Beauchemin, K.A., McGinn, S.M., Wang, Y., Harstad, O.M. and McAllister, T.A., 2011. Effects of replacing barley grain in feedlot diets with increasing levels of glycerol on in vitro fermentation and methane production, Animal feed science and technology, 166, 265-268

Avila-Stagno, J., Chaves, A.V., He, M.L., Harstad, O.M., Beauchemin, K.A., McGinn, S.M., and McAllister, T.A., 2013. Effects of increasing concentrations of glycerol in concentrate diets on nutrient digestibility, methane emissions, growth, fatty acid profiles, and carcass traits of lambs, Journal of animal science, 91, 829-837

Barros, M.C.C., De Araújo Marques, J., Silva, R.R., Da Silva, F.F., Costa, L.T., Guimarães, G.S., Silva, L.L. and Gusmão, J.J.N., 2015. Viabilidade econômica do uso da glicerina bruta em dietas para cordeiros terminados em confinamento, Semina: Ciências Agrárias, 36, 443-452

Chanjula, P., Pakdeechanuan, P. and Wattanasit, S., 2015. Effects of feeding crude glycerin on feedlot performance and carcass characteristics in finishing goats, Small Ruminant Research, 123, 95-102 
Donkin, S.S., Pallatin, M.R., Doane, P.H., Cecava, M.J., White, H.M., Barnes, E. and Koser, S.L., 2007. Performance of dairy cows fed glycerol as a primary feed ingredient, Journal of Animal Science, 90, 350-359

Gunn, P.J., Schultz, A.F., Van Emon, M.L., Neary, M.K., Lemenager, R.P. and Pas, C.P., 2010. Effects of elevated crude glycerin concentrations on feedlot performance, carcass characteristics, and serum metabolite and hormone concentrations in finishing ewe and wether lambs, The Professional Animal Scientist, 26, 298-306

Hall, M.B., 2000. Calculation of non-structural carbohydrate content of feeds that contain non-protein nitrogen, University of Florida, (Bulletin 339, April-2000)

Krehbiel, C.R., 2008. Ruminal and physiological metabolism of glycerin, Journal of Animal Science, 2, 392

Krueger, N.A., Anderson, R.C., Tedeschi, L.O., Callaway, T.R., Edrington, T.S. and Nisbet, D.J., 2010. Evaluation of feeding glycerol on free-fatty acid production and fermentation kinetics of mixed ruminal microbes in vitro, Bioresource technology, 101, 8469-8472

Lage, J.F., Paulino, P.V.R., Pereira, L.G.R., Duarte, M.S., Valadares Filho, S.C., Oliveira, A. S., Souza, N.K.P. and Lima, J.C.M., 2014 Carcass characteristics of feedlot lambs fed crude glycerin contaminated with high concentrations of crude fat, Meat science, 96, 108-113

Lanzas, C., Sniffen, C.J, Seo, S., Tedeschi, L.O. and Fox, D.G., 2007. A revised CNCPS feed carbohydrate fractionation scheme for formulating rations for ruminants, Animal Feed Science and Technology, $136,167-190$

Licitra, G., Hernandez, T.M. and Van Soest, P.J., 1996. Standardization of procedures for nitrogen fractionation of ruminant feeds, Animal Feed Science and Technology, 57, 347-358

Lund, P., Weisbjerg, M.R. and Hvelplund, T., 2007. Digestible NDF is selectively retained in the rumen of dairy compared to indigestible NDF, Animal Feed Science and Technology, 134, 1-17

Mauricio, R.M., Mould, F.L., Dhanoa, M.S., Owen, E., Channa, K.S. and Theodorou, M.K., 1999. A semi-automated in vitro gas production technique for ruminant feedstuff evaluation, Animal Feed Science and Technology, 79, 321-330

Meale, S.J., Chaves, A.V., Ding, S., Bush, R.D. and McAllister, T.A., 2013. Effects of crude glycerin supplementation on wool production, feeding behavior, and body condition of Merino ewes, Journal of animal science, 91, 878-885

Mello, R., Nörnberg, J.L., Queiroz, A.C., Miranda, E.N., Magalhães, A.L.R., David, D.B. and Sarmento, J.L.R., 2006. Composição química, digestibilidade e cinética de degradação ruminal das silagens de híbridos de girassol em diferentes épocas de semeadura, Revista Brasileira de Zootecnia, 35, 1523-1534

Mertens, D.R., 1992. Análise da fibra e sua utilização na avaliação de alimentos e formulação de rações. In: Simpósio Internacional de Ruminantes, Lavras, 1992, (Anais... Lavras: Sociedade Brasileira de Zootecnia), 188-219
Nocek, J.E., 1988. In situ and other methods to estimate ruminal protein and energy digestibility, A review, Journal of Dairy Science, 71, 2051-2069

Oliveira Filho, C.A.A., Azevêdo, J.A.G., Carvalho, G.G.P., Silva, C.F.P.G. and Santos, J.D., 2015. Glicerina bruta associada à silagem de sorgo em dietas para cordeiros, Arquivo Brasileiro de Medicina Veterinária e Zootecnia, 67, 474-482

Paggi, R.A., Fay, J.P. and Faverin, C., 2004. In vitro ruminal digestibility of oat hay and cellulolytic activity in the presence of increasing concentrations of short-chain acids and glycerol, Journal of Agricultural Science, 142, 89-96

Parsons, G.L., Shelor, M.K. and Drouillard, J.S., 2009. Performance and carcass traits of finishing heifers fed crude glycerin, Journal of Animal Science, 87, 653-657

Parsons, G.L. and Drouillard, J.S., 2010. Effects of crude glycerin on ruminal metabolism and diet digestibility in flaked corn finishing diets, Journal of Animal Science, 88, 96 (Abstr.)

Peripolli, V., Prates, Ê.R., Barcellos, J.O.J., Wilbert, C.A., Camargo, C., Lopes, R.B. and Costa Junior, J.B.G., 2014. Effect of crude glycerol on in-vitro ruminal fermentation kinetics, Revista Brasileira de Saúde e Produção Animal, 15, 172-181

Rogers, V., Fonty, G., Andre, C. and Gouet, P., 1992. Effects of Glycerol on the Growth, Adhesion, and Cellulolytic Activity of Rumen Cellulolytic Bacteria and Anaerobic Fungi, Current Microbiology, 25, 197-201

Sampaio, I.B.M., Pike, D.J. and Owen, E., 1995. Optimal design for studying dry matter degradation in the rumen, Arquivo Brasileiro de Medicina Veterinária e Zootecnia, 47, 373-383

Santos, M.G.M.F., Azevêdo, J.A.G., Pereira, L.G.R., Silva, T.C., Cabral, I.S. and Farias, D.S., 2010. Relação entre pressão e volume para implantação da técnica in vitro de produção de gases no trópico úmido. In: Reunião Anual da Sociedade Brasileira de Zootecnia, Salvador, 2010, (Anais... 47 , Salvador: Sociedade Brasileira de Zootecnia)

Schofield, P., Pitt, R.E. and Pell, A.N., 1994. Kinetics of fiber digestion from in vitro gas production, Journal of Animal Science, 72, 2980-2991

Souza, L.L., Azevêdo, J.A.G., de Araújo, G.G.L., dos Santos-Cruz, C.L., dos Santos Cabral, Í., de Almeida, F.M., de Oliveira, G.A. and Oliveira, B.S., 2015. Crude glycerin for Santa Inês and F1 Dorper $\times$ Santa Inês lambs, Small Ruminant Research, 129, 1-5

Theodorou, M.K., Williams, B.A., Dhanoa, M.S., Mcallan, A.B. and France, J., 1994. A simple gas production method using a pressure transducer to determine fermentation kinetics of ruminant feeds, Animal Feed Science Technology, 48, 185-197

Van Soest, P.J. and Robertson, J.B., 1985. Analysis of forages and fibrous foods, (Ithaca: Cornell University) 